\title{
The Role of E-Commerce Era Covid-19 in the Revolution of the Accounting Information Systems
}

Lesi Hertati

Indo Global Mandiri University-Palembang-Indonesia

Correspondence : hertatilesi@yahoo.co.id

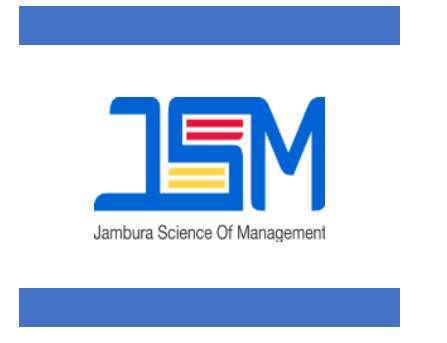

JSM

Volume 3

Number 2

July 2021

Received on 30 January

2021

Revised on 12 February

2021

Accepted on 13 February 2021

The journal allows the authors to hold the copyright without restrictions and allow the authors to retain publishing rights without restrictions. Authors retain copyright and grant the journal right of first publication with the work simultaneously licensed under a creative commons attribution 4.0 international license.

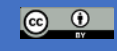

DOI: 10.37479

\section{ABSTRACT}

Purpose: The purpose of this study is to determine the effect of e.commmerce Era Covid-19, Corporate Strategy in the Covid-19 era on the accounting information system industrial revolution.

Design/Methodology/Approarch: The population of this research is 7000 employees of PT Freeport Indonesia, with a total sample of 852 employees obtained through simple random sampling. The purpose of this study is to determine the use of E-Commerce in the Covid-19 Era, the company's strategy in the Industrial Revolution accounting information system. This method is a descriptive and verification method, and the analytical tool is SEM Lisrel modeling.

Findings: The fact states that the influence of e.commerce, the company's strategy has various problems including the problem of collecting and storing data on organizational activities, resources and personnel, converting data into information so that management can plan, implement, control and evaluate activities, resources and personnel, provide adequate controls for storing organizational assets and data.

Keywords: E-Commerce; Corporate Strategy; Accounting Information System

\section{INTRODUCTION}

The demand for Internet applications is quite high due to the emergence of natural conditions caused by the Corona Virus which occurs suddenly, people are required to stay at home to avoid crowds of people who can transmit the Corona virus from person to person. The e-commerce information technology industry is one of the applications and applications of e-business related to commercial transactions, such as: electronic fund transfers, supply chain management, electronic marketing, or online marketing of online transaction processing, electronic data exchanges e part of e-business, where the scope of e-business is broader, not only in business but also includes collaborating with business partners, customer service, job openings. In addition to www network technology, e-commerce also requires database technology or a database of other forms of non-

P-ISSN: 2655-3651 E-ISSN: 2656-0435

P a g e $\mid 76$ 
computer technology such as goods delivery systems, and payment instruments for e-commerce (Susanto, 2014). Every organization needs quality information in order to make effective decisions (Romney and Steinbart, 2012: 25).

Furthermore Romney and Steinbart (2012: 25) say that to make effective decisions, organizations must decide what decisions are made, what information is needed and how to collect and process data to produce information. According to McLeod and Schell (2008: 34), the use of information can provide competitive advantages for companies. The information itself is defined as the result of data processing that gives meaning and benefits, while data is a fact or anything that can be used as input in producing information (Susanto, 2013: 38). In line with the above understanding (Hertati, 2016). McLeod and Schell (2008: 9) suggest data consists of facts and figures that are usually meaningless and not yet processed, while information is the result of data processing that has meaning, usually tells a thing that is not yet known by the user. Then according to Hall (2008: 3) information is a business resource. Like other business sources: raw capital and labor information is very important and indispensable for the survival of today business organizations (Hall, 2008: 3).

In fact, it was found that there was no quality information produced by the company, as stated by the Minister of Finance Mulyani (2009). He doubted the quality of data / information provided by Bank Indonesia regarding bank inspection in Indonesia. Then Boediono (2010) as vice president reminded banks to make quality reports. He emphasized that quality information is very important, banking financial statements must be accurate and do not do window dressing to look good. Information is generated through information systems (Gelinas and Dull, 2008: 13). Furthermore, Gelinas and Dull (2008: 13) said that an information system is a system that consists of a collection of integrated computer-based components and manual components created to collect, store and manage data and provide output in the form of information to users. Accounting information system is a special subsystem (a specialized subsystem) of information systems that aim to collect, process and report information relating to financial aspects of business activities (Gelinas and Dull, 2008: Hertati \& Syafarudin, 2018).

Research results Hertati (2015) suggest in the application of accounting information systems in companies (organizations), the reality shows that there are still various problems. These problems were among others raised by the Minister of Finance of the Republic of Indonesia Mulyani (2008). One of the problems found in the results of the Supreme Audit Agency (BPK) examination is that there are differences between the government and BPK on the application of accounting information systems. These differences include the application of the gross or net principle in recognition of oil and gas

P-ISSN: 2655-3651 E-ISSN: 2656-0435 
revenues, the classification of revolving funds and the consolidation of revenues in the central government financial statements (LKPP).

Furthermore Mulyani (2008) said that the Ministry of finance and the BPK need to find a solution as soon as possible to the differences in the realization of the accounting information system that is held in the general treasury of the country with the accounting system that is held in the state ministries / institutions. The next problem is the poor accounting information system put forward by the chairman of the BPK, Nasution (2008), who stated: 'Transparency and accountability of state financial reports is still low, the quality of ministry reports (state institutions / KL) and regions shows a tendency to deteriorate from year to year.

The low transparency and accountability of the country's financial statements, resulting in an opinion given by the BPK to the country's financial statements is not giving an opinion (disclaimer). The main reason for BPK giving a disclaimer opinion is that the accounting information and state reporting system is still weak. Furthermore Nasution (2009) also stated that the BPK rediscovered nine main issues relating to the granting of opinion disclaimer of the central government's financial statements. One of them is the lack of integration between the general accounting information system organized by the finance department and the agency accounting information system organized by the department / institution so that there is still a difference between the two. Furthermore, the head of Century Bank's investigative audit team from the Supreme Audit Agency (BPK) Bisri (2010) stated that there was a bank play and accounting engineering in the Century Bank case.

The bank game is engineered to become a loss, plotted from within and then the accounting is engineered as if the assets are good. Susanto (2014) states that accounting information systems are a unified arrangement in business enterprise entities that use physical resources and other components to convert economic data into accounting information, with the aim of satisfying the information needs of various users (Wilkinson et al., 2000: 7). Then the accounting information system is used as a tool for analyzing decisions or as decision makers related to company transactions (Susanto 2014: 17). The same thing was expressed by Gelinas and Dull (2008: 633), accounting information systems are a special subsystem of information systems that collect, process, and report information relating to financial aspects of business activities.

Furthermore Susanto (2014: 72) states that accounting information systems are a collection (integration) of sub-systems / components both physical and non-physical that are interconnected and work together in harmony to process transaction data related to financial problems be financial information. Then Romney and Steinbart (2012: 28) define accounting information systems are systems that

P-ISSN: 2655-3651 E-ISSN: 2656-0435 P a g e 78 
collect, record, store and process data to provide information for decision makers.

Quality information produced by accounting information systems is a characteristic of the effectiveness of the system (Mancini, at al., 2013: 141). Furthermore Mancini at al. (2013: 141) say an effective accounting information system can be called the ability of the system to provide information that can be used in accordance with needs. Then further Gelinas and Dull (2008: 39) state that the industrial revolution means that information must be appropriate and fully support the needs of users in supporting business processes and user tasks and presented in the right time and format, consistent with the previous format so that it is easy to understand. Based on the above definition, the notion of the industrial revolution 4.0 accounting information systems can be synthesized as a collection (integration) of sub-systems / components both physical and non-physical that are interconnected and work together in harmony in gathering, recording, storing and storing process data to provide information for decision makers.

An effective accounting information system will produce output in the form of quality accounting information (Kaluarachchi, 2015). According to Susanto (2014: 22) accounting information is defined as processed data that has financial meaning / value for users who need it for decision making purposes. While quality is a relatively good measure (Hansen and Mowen, 2005: 441). Susanto (2009: 11), states that quality is a match between the specifications required compared to the specifications produced (used) by the company. Based on the above definition, it can be synthesized the understanding of quality accounting information is an information that has financial meaning / value and is a relatively good measure and there is a match between the required specifications and the specifications produced. There are five criteria that characterize the quality of information, namely: materiality, relevance, reliability, comparability and understandability (Susanto, 2014: 22). Meanwhile, according to Gelinas and Dull (2008: 20), the quality of information includes: effectiveness, efficiency, confidentiality, integrity, availability, compliance and reliability.

Furthermore Susanto (2013: 13) revealed that accounting information generally has four dimensions of information quality, namely accurate, relevant, timely and complete. Based on the results of previous research and developing theories, there are several factors that can affect the effectiveness of accounting information systems that have an impact on the quality of accounting information, such as the use of e-commerce (Hurt, 2008: 297), the user's personality (Block, 2002; Kaluzniacky, 2004: 08;) and corporate strategy (Tukker et al, 2009: 436; Romney and Steinbart, 2012: 23; Romney and Steinbart, 2012: 33). The author will explain successively starting with the use of e-commerce. The use of electronic commerce (e- 
commerce) refers to the use of the internet and the web to conduct business transactions (Laudon and Laudon, 2007: 392). E-commerce is part of e-business related to the buying and selling of goods and services via the internet (Laudon and Laudon, 2017: 67).

E-business itself refers to the use of digital technology and the internet to run major business processes in the company (Laudon and Laudon, 2007: 67). While Hall (2008: 563), states that e-commerce involves the processing and transmission of data electronically. Hall further (2008: 563) said that this broad definition includes a variety of different activities including: electronic buying and selling of goods and services, online delivery of digital products, electronic funds transfer (EFT), electronic trading of stocks, and direct consumers marketing. Bodnar and Hopwood (2010: 21) states in terms of web commece. Web committee is selling through the world wide web which is an integral part of the economy. Furthermore Bodnar and Hopwood (2010: 21) said that selling through the web provides benefits for consumers and traders. Benefits for consumers include: "(1) There is no waiting in line for a sales or product information (2) through intelligent web-based software, customers can find fast answers to complicated questions relating to tea merchant's products (3) web- based transctions are normally encrypted, which provide enhanced security. Then Basu (2007) said that e-commerce is a broad concept that includes various commercial transactions that are influenced by media / electronic devices such as facsimile, telex, EDI, internet and telephone.

According to Laudon and Laudon (2017: 404) e-commerce is grouped into three categories namely Business to consumer (B2C) which involves the sale of products and services to individual buyers, Business to business (B2B) which involves selling goods and services between businesses, Consumer to consumer (C2C) which involves direct sales by consumers to consumers. Whereas McLeod and Schell (2008: 48) mention there are two types of e-commerce that occur with entities outside the company's boundaries, namely business to consumer (business to consumer / B2C) and business to business (business to business / B2B).

$\mathrm{B} 2 \mathrm{~B}$ refers to transactions that occur between a business and the final product customer, while $\mathrm{B} 2 \mathrm{C}$ refers to transactions between businesses where there is no phlegm of being the final consumer. In line with Turner and Copeland (2020: 569) said that e-commerce transactions include business to consumer (B2C) and business to business (B2B). The phenomena that occur are related to the use of ecommerce, among others: Bank Indonesia noted that there have been several crimes through internet banking, including falsification of web browsers, theft of IP addresses, passwords and hacking.

Other findings were stated by Tesong Kim (2012), Deruten \& Chief E-Commerce Consultant Rakuten. He said imitation goods alias KW are still sold freely on e-commerce sites and not a few large e- 
commerce sites in Indonesia still allow users to sell $\mathrm{KW}$ goods. If the seller does not provide information that the product he sells is $\mathrm{KW}$ goods, this can be detrimental to the buyer because they feel cheated. The use of e-commerce affects the accounting information system as stated by various experts. According to Deshmukh (2006: 9), the influence of the use of e-commerce on accounting is explained in different terms in the literature. Then Rama and Jones (2006: 506) states that companies can implement e-commerce applications in their accounting information systems. Through e-commerce allows digital commercial transactions between various organizations and each individual. (Laudon and Laudon, 2017: 392). Furthermore, Hertati (2015) said that e-commerce commercial transactions involve the exchange of value (for example money) with products or services through organizational and individual boundaries.

Based on the explanation above, through e-commerce accounting information systems can reach customers and suppliers that are far from the physical location of the company. Based on the results of research by Hertati (2015) and Ahmad (2013) the application / use of e-commerce affects the accounting information system. Furthermore Al-Refaee (2012) from the results of his research shows that ecommerce applications affect the design of accounting information systems, as well as the application of accounting information systems. Another factor that can influence the effectiveness of accounting information systems is that corporate strategy is a factor that can influence the accounting information system industry revolution. Romney and Steinbart (2012: 23) state that accounting information systems and corporate strategies influence one another. Furthermore Susanto (2014: 33) revealed that there are three factors that influence the design / application of accounting information systems, namely: development in information technology (development in IT), corporate strategy (corporate strategy) and organizational culture (organizational culture).

Then Tukker et al (2009: 436) also states that the accounting information system requires redesigned (redesigned) to facilitate the implementation (enforcement) of corporate strategy. According to Brian and Manning (1999: 82), corporate strategy is a term borrowed from the private sector, which refers to the main financial goals and social objectives. The organization will pursue key products, technologies and production processes that will rely on it to achieve its goals. It also defines how the organization will relate to its employees and other constituents such as shareholders, creditors, suppliers and customers.

Furthermore Brian and Manning (1999: 82) say in short, the company's strategy seeks to determine for the organization how the organization will pursue a value and how the organization will become. Then Bryan and Alen (2010: 15), said that the company's strategy in the beginning (1960s) and Hertati (2025) focused on 
making plans to compete successfully in business. Furthermore Bryan and Alen (2010: 192) said that the company's strategy is a pattern of decisions in the company that determines and expresses its goals.

The objectives produce the main policies and plans to achieve these goals and define the company's various efforts to pursue them. The phenomenon of global and domestic financial conditions that continues to deteriorate forced banks to conduct internal consolidation and formulate strategies so that potential losses can be minimized. The next phenomenon, data sharing research agency Vision from Bandung noted as much as 68 percent of 246.9 million people in Indonesia do not have a bank account. Then as much as 80 percent of the population aged 15 years and over have not been touched by banking services, and 52 percent of households do not have deposits in financial institutions.

Therefore a breakthrough is needed so that banking services can reach more residents, one of which is branchless banking or a bank without a branch office. Various empirical evidence relating to the influence of e.commerce on accounting information systems has been produced from various results of research conducted by researchers around the world. The results of a study conducted by Hertati et.al (2015) produced evidence that the e.commerce rate influenced the accounting information system industry revolution. Furthermore, research conducted by Indeje and Hertati (2015) shows empirical evidence that illustrates that e-commerce influences the implementation of Accounting Information Systems.

Likewise, research conducted by Hertati (2016), which proves that all dimensions of e.commerce have a positive and significant influence on the accounting information system industry revolution. Then the influence of the company's strategy on the accounting information system is proven by research conducted by $\mathrm{H}$ (201). The results of his research mentioned that the company's strategy together with accounting theory allows for the specification of a good accounting information system design. Likewise, research conducted by Yolande (1997: 125), from the analysis of data collected through a mail survey of manufacturing companies and financial service companies in North America shows that the orientation of the company's strategy is aligned with the information system strategy that is well modeled through a systems approach.

Rama and Jones (2006: 500) state that e-commerce is part of an ebusiness transaction that enables the buying and selling process through the web and appropriate network technology. Whereas McLeod and Schell (2008: 47) say that some people define ecommerce in a narrow way, which only includes business transactions related to customers (suppliers) and suppliers (suppliers) that connect their computers through the internet. Furthermore McLeod and Schell (2008: 47) add that a broad view / understanding of e-commerce can facilitate internal and external operations of the company. This means 
that business transactions can use network access, computer based systems and web browser interfaces. Then Hurt (2008: 293) said that e-commerce is the exchange of goods and services via the internet or other computer networks. Turner and Copeland (2020:346) states that when companies sell goods via the internet, this is called e-commerce. Furthermore Turner and Copeland $(2020 ; 569)$ say e-commerce is Web-based trading. Hall (2008: 563) says that e-commerce involves the processing and transmission of data electronically.

Hall further (2008: 563) said the broad definition includes a variety of different activities namely the buying and selling of goods and services, sending digital products online, transferring funds electronically (electronic fund transfer), trading of shares electronically and marketing consumers in an electronic manner live. Then Romney and Steintbart (2012: 806) define e-commerce as the execution of electronic business transactions such as buying and selling. Furthermore Basu (2007: 76) says that e-commerce is a broad concept that includes commercial transactions that are influenced by electronic devices such as facsimile, telex, EDI, internet and telephone. Based on the above definition, what is meant by ecommerce is a broad concept that includes commercial transactions that allow sales and purchases via the Web or appropriate network technology or use of media / electronic devices such as the internet, facsimile, telex, EDI, and telephone and the other. There are various dimensions that can be used to measure the use of e-commerce as stated by Laudon and Laudon (2017: 392) say that the dimensions used in measuring e-commerce usage are:

1. Ubiquity: Internet / web technology available anywhere and anytime.

In traditional trade, the market is a physical place like a retail shop visited for business transactions. E-commerce is everywhere, meaning that trade is available everywhere at any time. This allows customers to shop from their desktop whether at home, at work, or even in a car using mobile commerce.

2. Global rich: Technology crosses national borders throughout the world.

E-commerce technology allows trade transactions across cultural and national boundaries that are far and more convenient (convenient) and cost effective than traditional trade. As a result the size of the market in e-commerce is the same as the size of the world's online population.

3. Universal standards: There is a set of technological standards namely internet standards.

One striking feature of e-commerce technology is the technical standard of the internet. Therefore the technical standard for conducting e-commerce is a universal standard. This standard is shared by all countries around the world which allows all computers to connect with other computers regardless of the technology platform that uses them. 
4. Richness: Allows for video, audio and text messages.

Richness refers to the complexity and content of the message. The web makes it possible to transport a variety of messages through text, audio and video simultaneously to a large number of people.

5. Interactivity. Technology activities / work through interaction with users.

Unlike twentieth-century trading technology, except for the use of telephones, e-commerce technology is interactive. This means that e-commerce technology enables two-way communication between merchants and customers. Interactive enables online trading by engaging customers in the same way as face to face but on a global scale.

6. Information density: Technology reduces information costs and improves quality.

The internet and the Web greatly increase information density. The amount and quality of information available to all market participants, customers and suppliers. E-commerce technology reduces information collection, storage, processing and communication costs while increasing currency, accuracy and timeliness of information. Information density in the e-commerce market makes prices and costs more transparent.

7. Personalization / Customization. Technology allows personal messages to be conveyed to individuals or groups. E-commerce technology enables personalization: merchants can target their marketing messages to certain individuals by tailoring messages to someone's name, interests, and recent purchase.

E-Commerce, the industrial revolution influences the Accounting Information System Lubbe (2002: 65) states that the handling of ecommerce in the accounting information system is needed. According to Deshmukh (2006: 9), e-commerce influences the accounting information system through the use of the internet which is explained in different terms in the literature. Then Rama and Jones (2006: 506) said the implementation of e-commerce in the accounting information system can be in the form of order entry, cash collections, and provision of services. Whereas Hurt (2008: 297) mentions ecommerce creates and posts journal entries in accounting related to inventory information. Electronic network applications (such as ecommerce through the use of the internet) can change information and business process relationships between organizations and individuals.

This process includes the interaction between existing processes in the back office (internal) such as distribution, manufacturing and accounting with processes in the front office (external) such as organizational relationships with customers and suppliers (suppliers) (Gelinas and Dull, 2008: 64). Furthermore Gelinas and Dull (2008: 64) say the complexity of replacing paper records with electronic media (electronic one) is a challenge faced in overcoming differences in the technology and accounting systems that connect two corporate computer systems, which ultimately obstacles can be overcome for 
successful execution of business events (business events) via the internet.

Then Susanto (2014: 297) mentioned that a company's accounting information system is currently very dependent on telecommunications such as online data processing. Susanto (2014: 297) further said that the existence of the internet, intranet, extranet and electronic business (e-business or e-commerce) shows how the role of telecommunications is very important for the present and the future. Then Atabey et al. (2013: 98) mention the dynamic power of globalization is the most rapid development in communication and information technology (output of accounting information systems).

This development determines the form of trade (understanding), understanding (understanding), and the application of the digital era, especially e-commerce applications. Some researchers have previously examined the effect of e-commerce on accounting information systems, as was done by Parlakkaya (2005: 169), the results of his study showed that e-commerce affects accounting information systems. E-commerce not only changes the form of trade but also is a number of concepts such as electronic billing (electronic billing) and electronic archiving (electronic archiving) that affect accounting information systems.

Then Hertati (2015) conducted a study aimed at looking at the effect of e-commerce on accounting information systems at banks in Jordan. The importance of this study arises from the need to recognize ecommerce and accounting information systems as the biggest developments in the business world. The results of his research through statistical analysis conducted showed that e-commerce has a positive effect on accounting information systems.

Furthermore Al-Refaee (2012: 1479) conducted a study aimed at testing the effect of e-commerce on accounting information systems. The questionnaire was designed and distributed for accountants, heads of accounting departments, and financial managers at Islamic banks. The analysis using SPSS shows that e-commerce affects the accounting information system. Then Ahmad (2013: 1) conducted a study entitled the effect of e-commerce on accounting information systems, computerized processes and cost productivity. The study was conducted on companies in Jordan. The results of his research indicate that e-commerce has a positive influence on accounting information systems. Based on the description above, it can be said that ecommerce affects the effectiveness of accounting information systems.

Hertati (2015) defines a company strategy as a pattern of objectives, policies, and plans to achieve the stated objectives in such a way that is used to determine what business the company will run and how the company will become. Then Brian and Manning (1999: 82) say corporate strategy is a term borrowed from the private sector that 
refers to financial and social goals. The organization will pursue these goals, and the organization relies on the organization's main products, technology and production processes to achieve these goals. It also defines how the organization will relate to employees and other constituents and how the organization will pursue values and ultimately how the organization will become.

Continuing Melewar and Jenkins (2002: 76) defines the company's strategy as an element that underlies the organization's business. Meanwhile, Sekulic (2009: 270) said that a company's strategy is a pattern of decisions within a company that determines and reveals company objectives, produces key policies and plans to achieve these objectives, and ultimately determines the scope, character and results of company activities and their parts. Then according to Bryan and Alen (2010: 15) said the initial definition of corporate strategy from the 1960s focused on making plans to compete successfully in business. Furthermore, Bryan and Alen 2010: 192) said that the company's strategy is the pattern of decisions in the company in determining and expressing its objectives, the objectives of producing policies and plans to achieve these objectives and defining various business ventures. Based on the definitions above, the company strategy referred to in this study is the pattern of decisions in a company that determines its objectives, which results in policies and plans to achieve those goals. To measure corporate strategy, according to Nilson and Birger (2004: 192) dimensions of corporate strategy are:

1. Growth is

is the company's ability to increase size can place itself in the overall economic system or economic system for the same industry.

2. Knowledge is

Knowledge is very important for human civilization both in terms of technological progress, health, social sciences, and so on.

3. The potential for synergy is

Productive cooperative relationships and harmonious partnerships with stakeholders, to produce useful and quality work with the aim of influencing the behavior of individuals individually or in groups to interact, through dialogue with all groups, where their perceptions, attitudes and opinions are important to a success

4. Company level is

Managers who work together with others by organizing their activities together to realize the goals of the company while management has the same responsibilities and tasks, namely carrying out planning, organizing, directing and controlling.

5. Mobility is Form of dynamics in social structures where there is movement and change in the position of a person or group of people from one layer to another in society with certain patterns that govern the organization of a social group, social structure 
includes the nature of the relationship between individuals in groups and the relationship between individuals with his group.

The company's strategy influences the accounting information system industry revolution Tukker, et al (2009: 436). Then Romeny and Stainbart (2012: 23) say that corporate strategy and accounting information systems influence each other. Romney and Stainbart (2012: 33) further state that there are three factors that influence accounting information systems, one of which is a corporate strategy. Research supporting the theory that corporate strategy influences accounting information systems has been conducted by Lawrence (1978: 203) under the heading Strategic decision processes and the design of accounting information systems: Conceptual linkages. The results of his study show that corporate strategy and accounting theory allow the design specifications of the requirements of accounting information systems.

Then research conducted by Chan et al. (1997: 125), his study measures the strategic orientation of business, strategic orientation of information systems, and strategic alignment of information systems, and investigates their implications for the effectiveness of information systems and business performance. Analysis of data collected in the North American financial services mail survey and manufacturing companies shows that the strategic business orientation, strategic orientation of the information system, and strategic alignment of the information system affect the effectiveness of the information system. Then the strategic alignment of information systems is the best predictor of the effectiveness of information systems, and the effectiveness of information systems has a positive impact on business performance. Based on the description above, it can be said that the company's strategy influences the effectiveness of the accounting information system.

Hypothesis 2: Corporate strategy on the Industrial Revolution in accounting information systems.

According to Moscove et al. (1990: 9), accounting information systems are components of organizations that collect, classify, process, analyze, and communicate financial information for decision making by external companies (such as investors) and internal parties (especially management). Then Nash and Chinthia (1993: 7) say accounting information systems are systems that produce accounting information for the purpose of: (1) meeting organizational legal reporting requirements, (2) providing reliable accounting information for those who need it, and (3) protect the organization from possible risks arising from misuse of accounting data or the system itself. Wilkinson et al. (2000: 7) mentions the accounting information system is a unified structure within an entity, for example a business company that uses physical resources and other components to convert economic data into accounting information, with the aim of satisfying the information needs of various kinds user. Then according 
to Rama and Jones (2006: 13) accounting information system is a subsystem of management information systems that provides accounting and financial information and other information obtained in the routine process of accounting transactions.

Susanto (2013: 72) defines an accounting information system as a collection (integration) of sub-systems / components both physical and non-physical that are interconnected and work together in harmony to transform data into financial information. Then the definition of accounting information systems according to Bodnar and William (2010: 3) is a collection of resources, such as humans and equipment, which are designed to convert financial data and other data into information. Furthermore Romney and Steinbart (2012: 28) say an accounting information system is a system that collects, records, stores and processes data to provide information for decision makers. Based on the description above, what is meant by the accounting information system in this study is a collection of subsystems / components both physical and non-physical that are interconnected and work together in harmony to transform data into accounting information used by internal parties and external to decision making.

Rama and Jones (200: 6) state that the accounting information system aims to provide five uses of accounting information, namely: (1) Producing external reports, (2) Supporting routine activities, (3) Decision support, (4) Planing and control, (5) Implementing internal control. One significant factor of management's success in achieving organizational goals is the effectiveness of accounting information systems, and accounting information system users who have a large role in the effectiveness of the system (Dehghanzade et al., 2011: 167). Before discussing more about the effectiveness of accounting information systems, the author first discusses the notion of effectiveness. According to Susanto (2014: 82), effectiveness refers to the extent to which the program reaches its goals. While Alfred et al. (2007: 9) say effectiveness is a construct (construct) that involves several constituents who have certain expectations about what should be done and how the results will be. Then Gelinas and Dull (2009: 19) say effectiveness is information that is relevant and related to business processes that are delivered at the right time, right, consistently and can be used.

According to Garrity and Sanders (1998: 96), effective information systems are different from efficient information systems. An efficient information system focuses on internal requirements, while an effective information system focuses on the external requirements for the function of the information system. Then Nicolaou (2000: 94), said that an accounting information system is effective if the information available through transaction processing can meet user needs. Based on the description above, what is meant by the effectiveness of accounting information systems in this study is the

P-ISSN: 2655-3651 E-ISSN: 2656-0435 
ability of information systems to provide accounting information that can meet user needs in decision making. Dimensions of the success of the information system is the foundation for assessing the effectiveness of the function of information systems (Garrity and Sanders, 1998: 96) include:

1. System quality is

Users feel that using the system is easier, does not require much effort to use it, so more time to do other things that are likely to improve overall performance

2. Information quality is

The extent to which information can consistently meet the requirements and expectations of all those who need that information to carry out the process.

3. System Use is

Data procedure network developed in an integrated system with the aim of providing both internal and external information to management, for decision making.

4. User satisfaction is

The level of user feeling after comparing what they receive with their expectations if they are satisfied with the value provided by the product or service, is very likely to be a customer for a long time.

5. Individual impact is

Conflicts that have a greater scope besides attacking each other in general are conflicts of dislike which can be expressed physically or psychologically from one individual or group to another individual or group.

6. Organizational impact is

To the maximum of available resources, of course, it requires collaboration from each personnel and good performance, which is an indication that can be considered when the organization is said to be running well and there is a harmonious relationship between each personnel in the organization, one of which is an attitude of loyalty that given by personnel (employees) to the organization (company).

\section{METHODS}

The target populations of this study is all employees of PT Freeport Indonesia. Keep in mind the conceptual model shown in Figure 1, the review instrument established by utilizing previous studies. The characteristics of the variable hypothesis were designed using SEMLisrel five answers from 1 to 5. The measurement items of the current study consisted of seven variables which included the emergency scientific discovery AISE, I. The research data was collected with a questionnaire coming directly and sent a letter then collected 7,000 employees of PT Freeport Indonesia. After visiting PT Freeport Indonesia employees directly distributing questionnaires were distributed to them for their responses. 
The process of selecting and knowledge of lecturers is very important for collecting data for researchers, when investigating creativity, emphasizing the centralization of employee knowledge that is relevant to the concept of accounting information systems and thus can provide meaningful responses (Dul et al., 2011). Therefore, a total of 7,000 questionnaires were sent to all of PT Freeport Indonesia's employees from 935 people who responded. Overall, the data collection process has been taken for 4 months. The current research is not funded by any association. Investigation has also followed the rules of Dillman (1978) in considering moral and ethical actions.

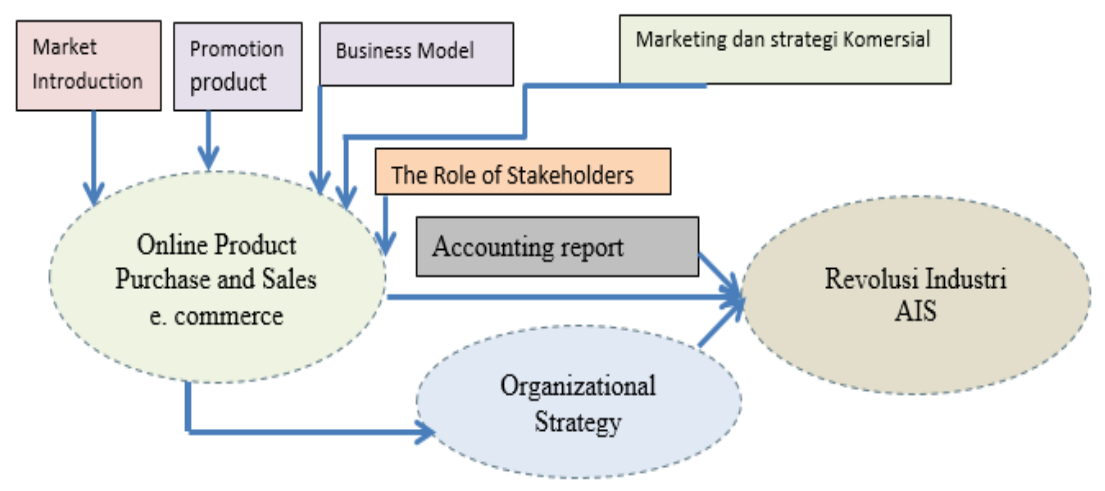

Figure 1. Research Framework

Hypotheses in ths study as Follows:

H1: E-commerce on the Industrial Revolution in accounting information systems.

$\mathrm{H} 2$ : Corporate strategy on the Industrial Revolution in accounting information systems

\section{RESULTS}

The method used in this research is descriptive and explanatory research. The population in this study were 7000 employees of PT Freeport Indonesia as many as 852 employees sampled through simple random sampling technique using the Slovin formula (Husein Umar, 2003: 141). Then the parameter estimation method in this study uses the maximum likelihood method with the assumption that multivariate data are normally distributed. At this stage, ensure that the model to be tested includes the under-identification model, namely df $<0$, the just-identified model, namely $\mathrm{df}=0$ or the overidentification model, $\mathrm{df}>0$. So that it can be calculated by the formula: $\mathrm{df}=1 / 2(\mathrm{p}+\mathrm{q})(\mathrm{p}+\mathrm{q}+1)-\mathrm{t} 2$.

Where:

$\mathrm{p}=$ number of indicators of exogenous variables, $\mathrm{q}=$ number of indicators of endogenous variables $t=$ number of parameters to be estimated Where $(p+q)$ is the number of directly observed variables, namely exogenous (p) and endogenous (q), while $t$ indicates the number of model parameters estimated. Based on the calculation of 
the degrees of freedom (df) above, this study has an overly identifiable model identification.

\section{Data Analysis}

The data analysis of this study was completed using SEM Lisrel statistical software. The final valid sample of this study was 853 after testing it was obtained that the data were processed respectively.

Table 1. Evaluation Results of Dimension Relevance Measurement

\begin{tabular}{|c|c|c|c|c|c|c|c|}
\hline Latent & Dimension & Weight & $\begin{array}{c}\text { Default } \\
\text { error }\end{array}$ & $\begin{array}{c}\text { value- } \\
\mathbf{Z}\end{array}$ & $\begin{array}{c}\text { Value- } \\
p\end{array}$ & Sig & Relevant \\
\hline \multirow[t]{7}{*}{ e.commerce } & Ubiquity & 0,19 & 0,011 & 17,12 & 0,000 & Sig & Relevant \\
\hline & Global rich & 0,44 & 0,006 & 68,65 & 0,000 & Sig & Relevant \\
\hline & Universal standards & 0,45 & 0,008 & 68,65 & 0,000 & Sig & Relevant \\
\hline & $\begin{array}{|ll|}\text { B.1.1 } & \text { Richness } \\
\end{array}$ & 0,43 & 0,004 & 38,65 & 0,000 & Sig & \begin{tabular}{|l} 
Relevant \\
\end{tabular} \\
\hline & B.1.2 Interactivity & 0,43 & 0,012 & 68,65 & 0,000 & Sig & Relevant \\
\hline & Information density & 0,46 & 0,016 & $58,6 \mathrm{l}$ & 0,000 & Sig & Relevant \\
\hline & Personalization/Customization & 0,43 & 0,004 & 38,65 & 0,000 & Sig & Relevant \\
\hline \multirow{5}{*}{$\begin{array}{l}\text { Company } \\
\text { Strategy }\end{array}$} & Growth & 0,40 & 0,017 & 22,67 & 0,000 & Sig & Relevant \\
\hline & Knowledge & 0,45 & 0,015 & 26,32 & 0,000 & Sig & Relevant \\
\hline & Potential synergies & 0,40 & 0,016 & 26,32 & 0,000 & Sig & Relevant \\
\hline & Company level & 0,43 & 0,012 & 68,65 & 0,000 & Sig & Relevant \\
\hline & Mobility & 0,40 & 0,014 & 26,32 & 0,000 & Sig & \begin{tabular}{|l|} 
Relevant \\
\end{tabular} \\
\hline \multirow{6}{*}{$\begin{array}{l}\text { Accounting } \\
\text { Information } \\
\text { System } \\
\text { Industrial } \\
\text { Revolution }\end{array}$} & System quality & 0,46 & 0,011 & 39,99 & 0,000 & Sig & Relevant \\
\hline & Information quality & 0,46 & 0,011 & 39,99 & 0,000 & Sig & \begin{tabular}{|l} 
Relevant \\
\end{tabular} \\
\hline & System Use & 0,43 & 0,012 & 68,65 & 0,000 & Sig & Relevant \\
\hline & System Use & 0,46 & 0,011 & 39,99 & 0,000 & Sig & Relevant \\
\hline & Individual impact & 0,43 & 0,012 & 68,65 & 0,000 & Sig & Relevant \\
\hline & Organizational impact & 0,46 & 0,011 & 39,99 & 0,000 & Sig & Relevant \\
\hline
\end{tabular}

Source: Results of calculation of score components with the $\mathrm{R}$ program

Based on information obtained from table 1, showing a P-value smaller than 0.05 then all dimensions are relevant as a measurement tool for each variable.

Table 2. Structural Model Parameters

\begin{tabular}{ccccccccc}
\hline $\begin{array}{c}\text { Conseq } \\
\text { uence }\end{array}$ & Mediator & Cause & $\begin{array}{c}\text { Standard } \\
\text { estimate }\end{array}$ & Estimated & $\begin{array}{c}\text { Default } \\
\text { error }\end{array}$ & Value-2 & Value-p & Information \\
AIS & - & e.Com & 0,40 & 0,360 & 0,20 & 1,51 & 0,041 & Significant \\
AIS & - & CS & 0,50 & 0,460 & 0,20 & 1,41 & 0,042 & Significant \\
& & \multicolumn{5}{c}{ Source: Output software lisrell 8.5} & &
\end{tabular}

Based on table 1, the positive estimation parameter with a p-value $(0.041)$ is smaller than 0.05 so it is accepted, so we need an accounting information system on e.commerce. The results of the second hypothesis state that the parameter estimate with a positive $\mathrm{p}$-value (0.042) is smaller than 0.05 so that $\mathrm{H} 0$ is accepted, so an accounting information system is needed in the company's strategy. Based on the information obtained from table 2, namely the interpretation of the results of the evaluation of the structural equation model. Standard estimate after all models have been tested and the model is in 
accordance with the data, the next step is to test the hypothesis. In this study, there are hypotheses that will be tested directly, as follows: The better e.commerce is the better in the Accounting Information System Industrial Revolution. - The better the corporate strategy, in the Accounting Information System Industrial Revolution.

\section{DISCUSSION}

The results show that the better the Accounting Information System Industrial Revolution, the better the e.commerce performance in the Era Covid-19. Phenomenon Gradually the better the Revolution Industry of the Accounting Information System, the better the performance of e.commerce in this research is proven. Phenomenon Gradually the better the Revolution Industry of the Accounting Information System, the better the performance of e.commerce in this research is proven. The phenomenon of accounting information systems is not good because e.commes has not been able to design information technology properly on the quality of the system, the quality of information, the use of the system, user satisfaction, improving individuals, improving organizations that are so complex.

The better the company's strategy, the more effective the accounting information system, this studio declares influence. The Revolution Industry of the Accounting Information System enables the accounting information system to run well in conducting important business, which is collecting and storing data about organizational, resource and personal activities. Can transform data into information so that management can be done, implemented, controlled and carried out, resources, and personal to store assets and organizational data of PT Freeport Indonesia. System usage, user satisfaction, improving individuals, enhancing organizations that are so complex. The better the company's strategy, the more effective the accounting information system, this studio declares influence.

The Revolution Industry of the Accounting Information System enables the accounting information system to run well in conducting important business, which is collecting and storing data about organizational, resource and personal activities. Can transform data into information so that management can be done, implemented, controlled and carried out, resources, and personal to store assets and organizational data of PT Freeport Indonesia. not good because e.commes has not been able to design information technology well on the quality of the system, the quality of information, the use of the system, user satisfaction, improving individuals, improving organizations that are so complex. The better the company's strategy, the more effective the accounting information system, this studio declares influence.

Research results Hertati, et,all (2020) suggest the Revolution Industry of the Accounting Information System enables the accounting information system to run well in conducting important business, 
which is collecting and storing data about organizational, resource and personal activities. Can transform data into information so that management can be done, implemented, controlled and carried out, resources, and personal to store assets and organizational data of PT Freeport Indonesia.

\section{CONCLUSION}

The findings of this study highlight the most important role of the effectiveness of accounting information systems that is influenced by commerse. This research implies that organizations must consider the company's strategy and strategy as a measure of the threat of effectiveness of accounting information systems that has the potential to impede accounting information systems. In the present case the study proposes that an effective accounting information system is the main strategy of e.commerse in the freeport mining company to assess carefully the possibility of external risks by diversifying the organization's dependency approach on manual equipment. Furthermore, the importance of an effective accounting information system as an important driver of e.commerce provides useful information.

This research shows that there is an error in understanding in order to increase effectiveness, reduce costs that do not add value, create new markets, expand the reach of the world market share to achieve the main objectives of the larger spider that supports the company's daily activities, supports the decision making process, helps managers the company in fulfilling its responsibilities to external parties. Finally, this research is also for the need to maintain the quality of good quality pure gold so that the accounting information system can be effective and the local workforce is more skilled then it will encourage the production of gold mines to be able to compete and dominate the world market.

\section{REFERENCES}

Ahmad, M. A. (2013). Effect of e-commerce on accounting information system, computerization process and cost productivity. American Journal of Computer Technology and Application, 1(1), 01-06.

Alfred, R., Shults, C., \& Seybert, J. (2007). Core indicators of effectiveness for community colleges. Amer. Assn. of Community Col.

Atabey, N. A., \& Y1lmaz, B. (2013). An Evaluation of Electronic Commerce in Terms of Accounting Information System in the Global Competitive Environment. International Conference on Eurasian Economies. 
Basu, S. (2007). Global perspectives on e-commerce taxation law. Ashgate Publishing, Ltd.

Bisri. H (2010). There is Accounting Engineering in Century Bank Case. The economy. Through http: // bisniskeuangan.kompas.com/read/2010/01/04

Block, J. (2002). Personality as an affect-processing system: Toward an integrative theory. Psychology Press.

Bodnar, George H. dan Hopwood, William C. (2010). Accounting Informastion Systems. Tenth Edition. Pearson Education, Inc. Publishing- Prentice Hall.

Boediono. (2010). Don't Make Strange Reports. National. Through http: // national. compass. com / read / 2010/04

Brian, Forst and Manning, Peter K. (1999). The Privatization of Policing: Two Views Bryan, W. Husted and Alen, David Bruce. 2010. Corporate Social Strategy: Stakeholder Engagement and Competitive Advantage.

Chan, Y. E., Huff, S. L., Barclay, D. W., \& Copeland, D. G. (1997). Business strategic orientation, information systems strategic orientation, and strategic alignment. Information systems research, 8(2), 125-150.

Dehghanzade, H., Moradi, M. A., \& Raghibi, M. (2011). A Survey of Human Factors' Impacts on the Effectiveness of Accounting Information Systems. International Journal of Business Administration, 2(4), 166.

Deshmukh, A. (2006). Digital accounting: The effects of the internet and ERP on accounting. IGI Global.

Dillman, D. A. (1978). Mail and telephone surveys: The total design method (Vol. 19). New York: Wiley.

Dul, J., Ceylan, C., \& Jaspers, F. (2011). Knowledge workers' creativity and the role of the physical work environment. Human resource management, 50(6), 715-734.

Garrity, E. J., \& Sanders, G. L. (Eds.). (1998). Information systems success measurement. Igi Global.

Gelinas, Ulric J. dan Dull, Richard B. (2008). Accounting Information System. International Student Edition. Thomson South Western. 
Gordon, L. A., Larcker, D. F., \& Tuggle, F. D. (1978). Strategic decision processes and the design of accounting information systems: conceptual linkages. Accounting, Organizations and Society, 3(3-4), 203-213.

Hall, James A. (2008). Accounting Information System. Sixth Edition. South Western: Cengage Learning.

Hansen, Don R. dan Mowen, Maryanne M. (2005). Management Accounting,7th edition, Cincinati-Ohio: South Western Publishing Co.

Hertati, L. (2015). Impact of uncertainty of environment and organizational cultural on accounting information system management and implications for managerial performance proposing a conceptual framework. International Journal of Economics, Commerce and Management United Kingdom, 3(12), 455.

Hertati, L. (2015). Internal control and ethics of quality management system accounting information and implications on the quality of accounting information management: Proposing a research framework. International Journal of Economics, Commerce and Management United Kingdom, 3(6), 902-913.

Hertati, L. (2015). Total quality management as technics on strategic management accounting. International Journal of Recent Advances in Multidisciplinary Research, 2(11), 942-949.

Hertati, L., \& Safkaur, O. (2019). Impact of Business Strategy on the Management Accounting: The Case of the Production of State-Owned Enterprises in Indonesia, South Sumatra. Journal of Asian Business Strategy, 9(1), 29-39.

Hertati, L., \& Sumantri, R. (2016). Just in Time, Value Chain. Total Quality Management, Part Of Technical Strategic Management Accounting. International Journal of Scientific \& Technology Research, 5(04), 180-191.

Hertati, L., \& Syafarudin, A. (2018). How the Implementation of the Industrial Revolution 4.0 Management Information System Influenced Innovation: The Case of Small and Medium Enterprises in Indonesia. Journal of Asian Business Strategy, 8(2), 52-62.

Hertati, L., \& Zarkasyi, I. (2015). Competence of human resources, the benefits of information technology on value of financial reporting in Indonesia. Research Journal of Finance and Accounting, 6(8), 12-18. 
Hertati, L., Safkaur, O., \& Simanjuntak, A. M. (2020). How to Align Management Commitments to the Successful Implementation of Management Accounting Information Systems in Manager Decision Making. Ilomata International Journal of Tax and Accounting, 1(2), 89-102.

Hertati, L., Susanto, A., Zarkasyi, W., Suharman, H., \& Umar, H. (2020). Pengujian Empiris Bagaimana Kualitas Sistem Informasi Akuntansi Yang Dipengaruhi Oleh Etika Organisasi Berimplikasi Terhadap Kualitas Informasi Akuntansi. Jurnal Ilmiah Akuntansi Rahmaniyah, 3(1), 88-107.

Hertati, L., Widiyanti, M., Desfitrina, D., Syafarudin, A., \& Safkaur, O. (2020). The Effects of Economic Crisis on Business Finance. International Journal of Economics and Financial Issues, 10(3), 236-244.

Hertati.L. \& Zarkasyi.W. (2015). Effect Of Competence User Information System, The Quality Of Accounting Information Systems Management And Implications Insatisfaction User Information System (State Owner In Sumatera Selatan. European Journal of Accounting, Auditing and Finance Research. 3, (2).35-60.

Hertati.L. Hertati. L. Zarkasyi. W.Suharman. H.Umar.H. (2019). The Effect of Human Resource Ethics on Financial Reporting Implications for Good Government Governance (Survey of Related Sub-units in State-owned Enterprises in SUMSEL). International Journal of Economics and Financial. 9(4), 267276.

Hurt, R. L., \& Zhen, F. (2008). Accounting information systems: Basic concepts and current issues. McGraw-Hill Irwin.

Kaluarachchi, D. G. P. (2015). Impact of computerized accounting information systems' effectiveness in increasing the efficiency of human capital.

Kaluzniacky, E. (2004). Managing psychological factors in information systems work: An orientation to emotional intelligence. IGI Global.

Laudon, Kenneth C. dan Jane Price Laudon. (2017). Management Information System: Managing The Digital Firm. Tenth Edition. Pearson Education, Inc. New Jersey.

Lesi, H. (2020). The Influence of Information Technology Covid-19 Plague Against Financial Statements and Business Practices. Ilomata International Journal of Tax and Accounting, 1(3), 122-131. 
Lubbe, S. (Ed.). (2002). The economic and social impacts of ecommerce. IGI Global.Mancini, Daniela, Vaassen, Eddy H. J. dan Dameri, Renata Paola. 2013. Accounting Information Systems for Decision Making. Springer

McLeod, Jr. Raymond dan Schell, George P. (2007). Management Information Systems. Tenth edition. Pearson Prentice Hall. New Jersey.

Melewar, T. C., \& Jenkins, E. (2002). Defining the corporate identity construct. Corporate reputation review, 5(1), 76-90.

Moscove, Stephen A., Simkin, Simon Mark G. \& Bagranoff, Nancy A. (1990). Accounting Information Systems: Concept, and practice for effective decision making, fourth edition.

Mulyani.S. (2008). Ministry of Finance and BPK Need to Be One. The economy. Through http: // financial business. kompas.com

Mulyani.S. (2009). Doubt BI Data. The economy. Through.http: // business finance. compass. Com / read / 2009/09/25

Nash, John F., Chinthia D Heagy. (1993). Accounting Information Systems, third editon

Nasution.A (2008). Low Government Financial Accountability. The economy. Through http: // business finance.kompas.com

Nicolaou, A. I. (2000). A contingency model of perceived effectiveness in accounting information systems: Organizational coordination and control effects. International Journal of Accounting Information Systems, 1(2), 91-105.

Nilsson, F., \& Rapp, B. (2005). Understanding competitive advantage: The importance of strategic congruence and integrated control. Springer Science \& Business Media.

Parlakkaya, Raif, (2005). Effects of Electronic Commerce and Accounting Practices. Journal of Economics and Administrative Sciences. 5(2). 169-170.

Rama, Dasaratha V. dan Jones, Frederick L. (2006). Accouting Information System, Internation Student Edition. Thomsom South Western.

Romney, M., Steinbart, P., Mula, J., McNamara, R., \& Tonkin, T. (2012). Accounting Information Systems Australasian Edition. Pearson Higher Education AU. 
Sekulić, V. (2009). Corporate strategy development and competitive advantage of enterprise. Economics and Organization, 6(03), 269-279.Susanto.A.2014. Accounting Information Systems: Structure-Control-Risk-Development. Bandung: Lingga Jaya.

Susanto. A. (2009). Management Information Systems: A Structured Approach to Development Risk. Bandung: Lingga Jaya.

Tesong Kim. (2012). E-Commerce Sites Not Free of KW Goods. Through http: / techno. Kompas .com / read / 2012/06/09/15293675 / Situs.E-Comm.

Tukker, A., Schaltegger, S., Bennett, M., Burritt, R. L., \& Jasch, C. (2009). Environmental Management Accounting for Cleaner Production. Springer.

Turner, L., Weickgenannt, A. B., \& Copeland, M. K. (2020). Accounting information systems: controls and processes. John Wiley \& Sons.

Wilkinson, Joseph W., Cerullo, Michael J., Vasant Raval dan Wing, Bernard Wong-On. (2000). Accounting Information Systems: Essential Concepts and Application. Forth edition, John Wiley and Sons, Inc. 